\title{
Effects of lactic acid bacteria inoculation in pre-harvesting period on fermentation and feed quality properties of alfalfa silage
}

\author{
İbrahim Ertekin $^{1, *}$ and Mustafa Kızılşimşek ${ }^{2}$
}

* Corresponding Author: Ibrahim Ertekin Tel: +90-545-259-0187, Fax: +90-326-245-5832,

E-mail: ibrahim.ertkn@hotmail.com

${ }^{1}$ Department of Field Crops, Faculty of Agriculture, Hatay Mustafa Kemal University, Hatay, 31060,

Turkey

2 Department of Field Crops, Faculty of Agriculture, Kahramanmaraş Sütçü Imam University,

Kahramanmaraş, 46040, Turkey

ORCID

Ibrahim Ertekin

https://orcid.org/0000-0003-1393-8084

Mustafa Kızılşimşek

https://orcid.org/0000-0002-0295-0603

Submitted Oct 24, 2018; Revised Dec 5, 2018; Accepted Mar 24, 2019
Objective: To develop the fermentation quality and chemical composition of alfalfa (Medicago sativa Lam.) silage, plants were inoculated with different lactic acid bacteria (LAB) strains at field 24 hours before harvest.

Methods: The treatment groups were as follow: silage without additive as a control and inoculated with each strains of Lactobacillus brevis (LS-55-2-2), Leuconostoc citerum (L. citerum; L-70-6-1), Lactobacillus bifermentans (L. bifermentans; LS-65-2-1), Lactobacillus plantarum (L. plantarum; LS-3-3) and L. plantarum (LS-72-2). All the silages were stored at $25^{\circ} \mathrm{C}$. Parameters such as $\mathrm{pH}$, microorganism and volatile fatty acid contents, crude protein, neutral detergent fiber, acid detergent fiber, net gas, metabolizable energy, organic matter digestibility, dry matter intake and relative feed value were measured to determine fermentation quality, chemical compositions and relative feed value of alfalfa silages.

Results: Significant differences were found among the control and treated groups in terms of $\mathrm{pH}$ and microorganism contents at all opening times and crude protein, net gas, metabolizable energy and organic matter digestibility of final silage. The $\mathrm{pH}$ values ranged from 4.70 to 5.52 for all treatments and control silage had the highest value of overall treatments at $\mathrm{T}_{75} \mathrm{~d}$ silages. Volatile fatty acid of silages was not influenced significantly by inoculations. However, lactic acid content of L. bifermentans (LS-65-2-1) was higher than the other treatments. The highest metabolizable energy and organic matter digestibility were recorded from L. citerum (L-70-6-1) inoculation. In addition, no significant differences were found among treatments in terms of neutral detergent fiber, acid detergent fiber, dry matter intake and relative feed value.

Conclusion: Among the treated LAB isolates, L. bifermentans came into prominence especially in terms of organic acid composition and quality characters of silages.

Keywords: Alfalfa Silage; Feed Quality; Fermentation Characteristics; Inoculation; Lactic Acid Bacteria

\section{INTRODUCTION}

Alfalfa, the most cultivated forage in Turkey as well as in the world, is a very substantial leguminous forage crop, grown in warm-season belt and better in quality than grass forage plants. Since alfalfa is a perennial forage crop, it can be mowed more than once in a year and generally used as dry herbage for ruminants. However, farmers have usually faced some drying problems for the first or last cutting of the alfalfa because of possible precipitation [1]. Furthermore, nutrient loss may rise to $30 \%$ under bad conditions resulting serious economic loses. Ensiling alfalfa may be a good practice in terms of eliminating the necessity of drying fresh forage and preventing nutrient loses. However, alfalfa is difficult to ensile because of its buffering capacity preventing $\mathrm{pH}$ drop [2-4], lack of water soluble carbohydrate (WSC) necessary for microbial proliferation during fermentation [2,5], and its relatively low dry 
matter (DM) content at harvest. The DM and water-soluble carbohydrate (WSC) is low and the buffering capacity is high, which prevents the $\mathrm{pH}$ value from falling as much as possible during the ensiling process [6-9]. One of the most important issues in silage production is to reduce $\mathrm{pH}$ value as fast as possible [10]. Silage fermentation is created with the supply of media acidity by using WSC via epiphytic bacteria under anaerobic conditions [11]. It is reported that the epiphytic lactic acid bacteria (LAB) on the fresh forages may be inadequate therefore rapid and sufficient $\mathrm{pH}$ drop may not be achieved $[6,12]$. Hence, LAB inoculation before ensiling the forages could help improving silage fermentation profile and enhancing feed quality $[13,14]$. Bacterial treatments for improving silage quality were usually applied on silage material at postharvesting and pre-ensiling period in the previous studies, however experiments on inoculation at the pre-harvesting period in the field treatments are rare. Therefore, this study was carried out to determine the effects of pre-harvest inoculation of new LAB strains on alfalfa silage fermentation profile and feed quality.

\section{MATERIALS AND METHODS}

Plant, bacteria and rumen fluid providing animals Alfalfa, "Elci" cultivar, obtained from the farmer's field as second cut was inoculated with LAB in pre-harvesting period ( 24 before hours harvest). The LAB strains used as inoculant and their strain numbers as follows; Leuconostoc citerum ( $L$. citerum; L-70-6-1), Lactobacillus bifermentans (L. bifermentans; LS-65-2-1), Lactobacillus plantarum (L. plantarum; LS3-3) L. plantarum (LS-72-2) and Lactobacillus brevis (L. brevis; LS-55-2-2). L. brevis strain is heterofermentative while the others are homofermentative. All the strains were isolated from Turkey's rangeland flora within the scope of a project supported by Turkish Scientific and Technical Research Organization (TUBITAK). The isolates were selected among 695 isolates considering their acid production capacity in a given time period (data not given).

To apply the in vitro gas production technique, three Holstein cows were used as animal donors to provide rumen fluid. The cows were fed on ration based on corn silage and intensive feed mix (19\% crude protein, 2,850 kcal/kg DM). Roughage and intensive feed rate is $1 / 1$ based on dry matter and rumen fluid was collected via rumen fistula.

\section{Silage preparation}

Alfalfa at the $50 \%$ flowering period (DM about $370 \mathrm{~g} / \mathrm{kg}$ ) was theoretically inoculated with a density of $10^{5} \mathrm{cfu} / \mathrm{g}$ fresh weight with 5 bacterial inoculants prior to 24 hours from cutting on the field. Field inoculations were made at $12 \mathrm{~m}^{2}$ parcels with three replications and $3 \mathrm{~m}$ of interspace were given between each application in order to prevent any con- tamination. Fresh forage yield was estimated by cutting $1 \mathrm{~m}^{2}$ of alfalfa and weighted just before inoculation and application dosages were calculated and inoculation was done by spraying with an atomizer. A day after inoculation on the field, crops were cut by hand and chopped in 2 to $3 \mathrm{~cm}$ lengths via lab-type chopping machine. The machine was cleaned by $70 \%$ alcohol after chopping each treatment in order to prevent any contamination. Chopped forage materials were ensiled into plastic vacuum-package with $400 \pm 40 \mathrm{~g}$ with three replications for all opening times by means of vacuum sealer which removed $99.9 \%$ of $\mathrm{O}_{2}$ from the silage bag.

To monitor the microbial growth and $\mathrm{pH}$ changes for the first 48 hours of ensiling, silages were opened at $\mathrm{T}_{0}$ (just before ensiling), $T_{6}$ (six hours after ensiling), $T_{12}$ (twelve hours after ensiling), $\mathrm{T}_{24}$ (twenty-four hours after ensiling), and $\mathrm{T}_{48}$ (forty-eight hours after ensiling). For $\mathrm{T}_{0}$ time, samples were taken just before ensiling. For $\mathrm{T}_{6}, \mathrm{~T}_{12}, \mathrm{~T}_{24}$, and $\mathrm{T}_{48}$ openings 3 vacuum silages for each application $(6 \times 4 \times 3=72$ silos) were made separately. For the final silage $\left(\mathrm{T}_{75} \mathrm{~d}\right.$ or 75 days after ensilage) analysis, three replicated vacuum silages containing $500 \pm 50 \mathrm{~g}$ of each treatment were prepared.

\section{Microbiological and chemical analyzes}

At the times $\mathrm{T}_{0}$ and $\mathrm{T}_{75} \mathrm{~d}, 50 \mathrm{~g}( \pm 0.5 \mathrm{~g})$ of samples were separated and incubated at $78^{\circ} \mathrm{C}$ for 48 hours to determine the chemical compositions of each treatment. At all opening times, $20 \mathrm{~g}$ of the silage sample were mixed with $180 \mathrm{~mL}$ Ringers solution by a hand blender for 90 seconds at high speed and then filtered with Whatman 55 paper in order to get water extract. Microorganism counts, and $\mathrm{pH}$ measurements were made by using water extract of samples. Appropriate 10 fold dilution series were prepared for counting microorganisms. LAB counts were made in double layer MRS (De Man, Rogosa, and Sharpe) agar under anaerobic conditions incubated at $37^{\circ} \mathrm{C}$ for 48 hours. Counts of mold and yeast were enumerated in malt extract agar (MEA) at $37^{\circ} \mathrm{C}$ for 48 hours. Numbers of enterobacteria were evaluated in violet red bile glucose agar after incubation at $33^{\circ} \mathrm{C}$ for 18 hours.

Crude protein content was determined according to the Kjeldahl method and crude fat content of silages was determined by extraction method [15]. Crude ash content was detected in an ash furnace by burning at $550^{\circ} \mathrm{C}$ for 4 hours. Cell wall components such as neutral detergent fiber (NDF) and acid detergent fiber (ADF) were evaluated with ANKOM Fiber Analyzer (ANKOM Technology Corp., Fairport, NY, USA) according to the method described by Van Soest et al [16]. The Gas Production Technique reported by Menke and Steingass [17] was used to evaluate the digestibility properties under in vitro conditions of silages. In this way, 100 $\mathrm{mL}$ special syringes (Model Fortuna, Häberle Labortechnik, Lonsee-Ettlenschieb, Germany) were used to determine the gas production of the silages. Metabolic energy level of feeds 
was determined according to Blümmel and Orskov [18] and organic matter digestibility was calculated according to the reported method by Menke et al [19].

$$
\begin{aligned}
& \text { Metabolizable energy }(\mathrm{ME}, \mathrm{MJ} / \mathrm{kg} \mathrm{DM}) \\
& =2.20+0.136 \times \mathrm{GP}+0.0057 \times \mathrm{CP}+0.00029 \times \mathrm{CF}^{2} \\
& \text { Organic matter digestibility }(\mathrm{OMD} \%) \\
& =14.88+0.8893 \times \mathrm{GP}+0.0448 \times \mathrm{CP}+0.0651 \times \mathrm{CA}
\end{aligned}
$$

Where; GP, amount of gas produced (mL/200 mg) after 24 hours fermentation; $\mathrm{CP}$, crude protein content of silage (g/kg DM); CF, crude fat content of silage (g/kg DM); CA, crude ash content of silage ( $\mathrm{g} / \mathrm{kg} \mathrm{DM}$ ).

Dry matter digestibility (DMD), dry matter intake (DMI), and relative feed value (RFV) of silages were calculated by the following formulas developed by Van Dyke and Anderson [20]. DMD values were used to calculate the RFV.

$$
\begin{aligned}
& \operatorname{DMD}(\%)=88.9-(0.779 \times \mathrm{ADF} \%) \\
& \operatorname{DMI}(\%)=120 / \mathrm{NDF} \% \\
& \mathrm{RFV}=\mathrm{DMD} \% \times \mathrm{DMI} \% \times 0.775
\end{aligned}
$$

Lactic acid (LA), volatile fatty acids (VFA) (acetic acid [AA], butyric acid [BA], and propionic acid [PA]) and ethanol (ETOH) content of $\mathrm{T}_{75} \mathrm{~d}$ silages were made by using high pressure liquid chromatography at $42^{\circ} \mathrm{C}, 0.6 \mathrm{~mL} / \mathrm{min}$ flow rate and by using refractive index detector described by Quiros et al [21] after the sample cleaning procedure.

\section{Statistical analyzes}

The statistical evaluation of the data obtained in this study was made using the statistics program of MINITAB 17. The general linear model was used to determine the differences among the means and the Tukey pairwise $(\mathrm{p}<0.05)$ test was used to determine the significance level of the differences observed.

\section{RESULTS}

\section{Chemical composition of alfalfa before the ensiling} The mean values and statistical groups $\mathrm{CA}, \mathrm{CP}, \mathrm{NDF}, \mathrm{ADF}$, and $\mathrm{pH}$ of the alfalfa at the time $\mathrm{T} 0$ are given in Table 1 . The beginning CA values ranged from 80.02 to $86.16 \mathrm{~g} / \mathrm{kg} \mathrm{DM}$, while the CP content was between 182.53 and $209.74 \mathrm{~g} / \mathrm{kg}$ DM. NDF content values changed between 453.01 and 502.54 g/kg DM, while ADF values ranged from 276.89 to 311.90 $\mathrm{g} / \mathrm{kg}$ DM. However, these differences among mean values of $\mathrm{CA}, \mathrm{NDF}$, and ADF contents were not statistically significant. Differences among initial $\mathrm{pH}$ and $\mathrm{CP}$ content of alfalfa forage were statistically significant even though they were very close to each other ranging from 5.99 to 6.10 and 182.53 and 209.74 g/kg DM, respectively.

\section{$\mathrm{pH}$ changing of silages}

As it is seen in Table 2, the $\mathrm{pH}$ values at T0 opening time were around 6.07 for all treatments and decreased progressively from $\mathrm{T}_{0}$ to $\mathrm{T}_{75} \mathrm{~d}$. The lowest $\mathrm{pH}$ values were recorded from $L$. plantarum LS-72-2 treatment at the $\mathrm{T}_{12}$ and $\mathrm{T}_{24}$. Also, $\mathrm{pH}$ value of $L$. plantarum LS-72-2 was similar with $L$. bifermentans and L. plantarum LS-3-3 at the $\mathrm{T}_{24}$. L. bifermentans (LS-65-2-1), L. plantarum (LS-3-3) and L. plantarum (LS-72-2) treatments gave the lowest $\mathrm{pH}$ values for $\mathrm{T}_{48}$ with 5.08 which is the same for all three treatments. The $\mathrm{pH}$ value of control treatment for $\mathrm{T}_{75} \mathrm{~d}$ was 5.52 which is statistically higher than all inoculant treatments. All inoculant treatments were statistically similar in terms of $\mathrm{pH}$ values at $\mathrm{T}_{75} \mathrm{~d}$ opening time and all values, except $L$. plantarum LS-3-3, were below the level of 5.00.

\section{Microorganism changing of silages}

The changes in the number of enterobacteria, LAB, yeast and mold in the silages from the beginning to resulting silage are given in Tables 3, 4. The microorganism contents of silages from $\mathrm{T}_{0}$ to $\mathrm{T}_{75} \mathrm{~d}$ were highly variable. Enterobacteria, yeast

Table 1. The chemical compositions of each treatment sample of the alfalfa used as the silage material at the time T0

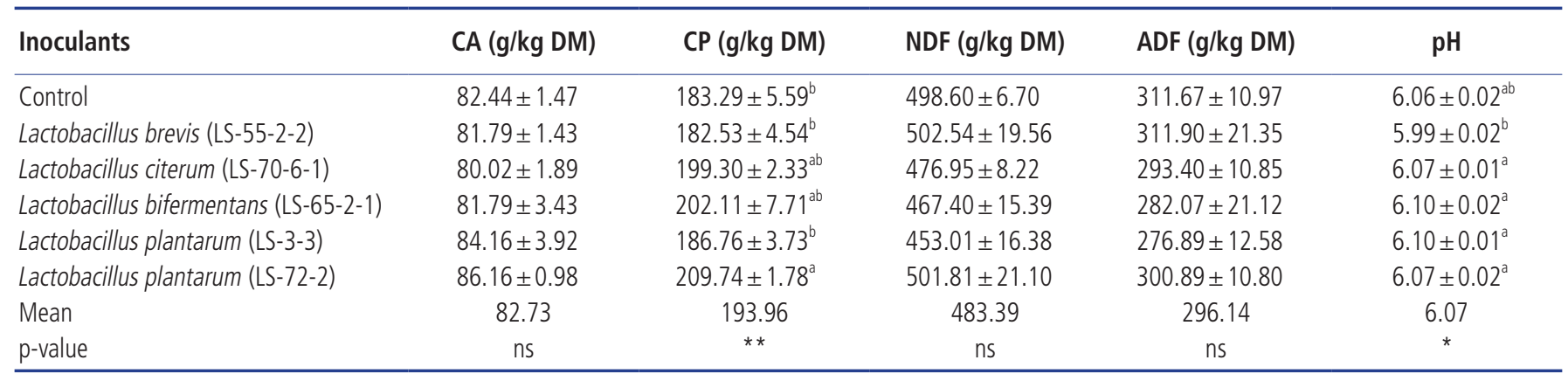

CA, crude ash; DM, dry matter; $C P$, crude protein; NDF, neutral detergent fiber; ADF, acid detergent fiber; pH, power of hydrogen; ns, non-significant.

a,b Mean values with diffent superscripts have significant difference. ${ }^{* *} p<0.01 ;{ }^{*} p<0.05$. 
Table 2. Effects of different bacterial inoculants on pH values of ensiled silages at different silage opening times

\begin{tabular}{lcccccc}
\hline Inoculants & $\mathrm{T}_{0}$ & $\mathrm{~T}_{6}$ & $\mathrm{~T}_{12}$ & $\mathrm{~T}_{24}$ & $\mathrm{~T}_{48}$ & $\mathrm{~T}_{75} \mathbf{d}$ \\
\hline Control & $6.06 \pm 0.02^{\mathrm{ab}}$ & $6.07 \pm 0.01^{\mathrm{a}}$ & $6.02 \pm 0.01^{\mathrm{a}}$ & $5.75 \pm 0.05^{\mathrm{a}}$ & $5.93 \pm 0.03^{\mathrm{a}}$ & $5.52 \pm 0.09^{\mathrm{a}}$ \\
Lactobacillus brevis (LS-55-2-2) & $6.00 \pm 0.02^{\mathrm{b}}$ & $6.00 \pm 0.02^{\mathrm{ab}}$ & $5.82 \pm 0.01^{\mathrm{ab}}$ & $5.40 \pm 0.03^{\mathrm{ab}}$ & $5.22 \pm 0.04^{\mathrm{bc}}$ & $4.83 \pm 0.02^{\mathrm{b}}$ \\
Lactobacillus citerum (LS-70-6-1) & $6.07 \pm 0.01^{\mathrm{a}}$ & $6.03 \pm 0.02^{\mathrm{ab}}$ & $5.94 \pm 0.02^{\mathrm{ab}}$ & $5.73 \pm 0.15^{\mathrm{a}}$ & $5.36 \pm 0.07^{\mathrm{b}}$ & $4.79 \pm 0.00^{\mathrm{b}}$ \\
Lactobacillus bifermentans (LS-65-2-1) & $6.10 \pm 0.02^{\mathrm{a}}$ & $6.06 \pm 0.02^{\mathrm{a}}$ & $5.84 \pm 0.03^{\mathrm{ab}}$ & $5.33 \pm 0.05^{\mathrm{b}}$ & $5.08 \pm 0.03^{\mathrm{c}}$ & $4.70 \pm 0.02^{\mathrm{b}}$ \\
Lactobacillus plantarum (LS-3-3) & $6.10 \pm 0.01^{\mathrm{a}}$ & $6.00 \pm 0.02^{\mathrm{ab}}$ & $5.98 \pm 0.04^{\mathrm{a}}$ & $5.28 \pm 0.07^{\mathrm{b}}$ & $5.08 \pm 0.01^{\mathrm{c}}$ & $5.00 \pm 0.05^{\mathrm{b}}$ \\
Lactobacillus plantarum (LS-72-2) & $6.07 \pm 0.02^{\mathrm{a}}$ & $5.97 \pm 0.01^{\mathrm{b}}$ & $5.72 \pm 0.11^{\mathrm{b}}$ & $5.18 \pm 0.04^{\mathrm{b}}$ & $5.08 \pm 0.02^{\mathrm{c}}$ & $4.92 \pm 0.15^{\mathrm{b}}$ \\
Mean & 6.07 & 6.02 & 5.89 & 5.45 & 5.29 & 4.91 \\
p-value & $* *$ & $* *$ & $*$ & $* * *$ & $* * *$ & $* *$ \\
\hline
\end{tabular}

$T_{0}$, fresh plants before ensiling; $T_{6}$, six hours after ensiling; $T_{12}$, twelve hours after ensiling; $T_{24}$, twenty-four hours after ensiling; $T_{48}$, forty-eight hours after ensiling; $T_{75} d$, seventy-five days after ensiling.

${ }^{a-c}$ Mean values with diffent superscripts have significant difference. ${ }^{*} p<0.05 ;{ }^{* *} p<0.01 ;{ }^{* * *} p<0.001$.

and mold that are harmful for silage quality first increased till $\mathrm{T}_{6}$ opening times, then decreased dramatically for $\mathrm{T}_{75} \mathrm{~d}$ silages. The number of enterobacteria in silages was generally higher in control treatment than inoculated silages at all opening times. Number of enterobacteria at $\mathrm{T}_{48}$ was higher than that of $\mathrm{T}_{0}$ meaning that they increased in the earlier phases of fermentation although enterobacteria counts were lower more than thousand times at $\mathrm{T}_{75} \mathrm{~d}$ openings compared to $\mathrm{T}_{48}$ counts. Numbers of enterobacteria ranged between 1.96 and $3.71 \log _{10} \mathrm{cfu} / \mathrm{g}$ for L. brevis (LS-55-2-2) and L. plantarum (LS-72-2), at the time $\mathrm{T}_{75} \mathrm{~d}$ while their counts at $\mathrm{T}_{48}$ were 6.79 and $6.58 \log _{10} \mathrm{cfu} / \mathrm{g}$, respectively.

The LAB, that are very significant for silage quality, increased in silos from $T_{0}$ to $T_{75} d$ silage. Numbers of $L A B$ ranged between 3.99 and $2.42 \log _{10} \mathrm{cfu} / \mathrm{g}$ at $\mathrm{T}_{0}$ and 6.11 and $7.35 \log _{10}$ cfu/g for L. bifermentans (LS-65-2-2) and control silage, respectively at $\mathrm{T}_{75} \mathrm{~d}$ opening time. Number of molds linearly dropped from the beginning to the end of ensiling period. Yeast counts decreased 10 to 100 times at $T_{48}$ compared to $T_{0}$ samples and they were undetectable at $T_{75} \mathrm{~d}$ openings.

\section{Volatile fatty acid contents of $\mathrm{T}_{75} \mathrm{~d}$ silages}

The LA, VFA such as AA, BA, and PA and ETOH contents of alfalfa silages in the different experimental treatments at the time $\mathrm{T}_{75} \mathrm{~d}$ are given at Table 5 .

LA content of silages changed between $0.659 \%$ in fresh matter from L. plantarum (LS-3-3) and 1.484\% fresh matter from L. bifermentans (LS-65-2-1). Only L. citerum (LS-70-6-1) and L. bifermentans (LS-65-2-1) treatments produced more LA than control treatment while other inoculant treatments pro-

Table 3. Effects of different bacterial inoculants on numbers of enterobacteria and lactic acid bacteria of ensiled silages at different silage opening times

\begin{tabular}{|c|c|c|c|c|c|c|}
\hline Inoculants & $\mathrm{T}_{0}$ & $\mathrm{~T}_{6}$ & $\mathrm{~T}_{12}$ & $\mathrm{~T}_{24}$ & $\mathrm{~T}_{48}$ & $T_{75} d$ \\
\hline \multicolumn{7}{|l|}{ Enterobacteria ( $\log _{10}$ cfu/g in fresh matter) } \\
\hline Control & $5.60 \pm 0.06$ & $7.02 \pm 0.10^{\mathrm{a}}$ & $7.22 \pm 0.07^{\mathrm{a}}$ & $7.71 \pm 0.09^{\mathrm{a}}$ & $6.58 \pm 0.02^{\mathrm{a}}$ & $3.59 \pm 0.20^{\mathrm{a}}$ \\
\hline Lactobacillus citerum (LS-70-6-1) & $5.20 \pm 0.21$ & $6.32 \pm 0.05^{c}$ & $5.10 \pm 0.10^{b}$ & $7.39 \pm 0.07^{\mathrm{ab}}$ & $6.68 \pm 0.17^{\mathrm{a}}$ & $2.99 \pm 0.12^{\mathrm{ab}}$ \\
\hline Lactobacillus bifermentans (LS-65-2-1) & $4.99 \pm 0.03$ & $6.75 \pm 0.12^{\mathrm{ab}}$ & $5.66 \pm 0.56^{b}$ & $6.98 \pm 0.05^{c}$ & $6.72 \pm 0.03^{\mathrm{a}}$ & $2.68 \pm 0.28^{\mathrm{ab}}$ \\
\hline Lactobacillus plantarum (LS-3-3) & $5.17 \pm 0.17$ & $6.60 \pm 0.03^{b c}$ & $6.47 \pm 0.10^{\mathrm{ab}}$ & $7.07 \pm 0.05^{\mathrm{bc}}$ & $6.97 \pm 0.11^{\mathrm{a}}$ & $3.33 \pm 0.41^{\mathrm{a}}$ \\
\hline Mean & 5.36 & 6.55 & 6.05 & 7.03 & 6.58 & 3.04 \\
\hline p-value & ns & $* * *$ & $* *$ & $* * *$ & $* * *$ & $\star \star$ \\
\hline \multicolumn{7}{|l|}{ Lactic acid bacteria ( $\log _{10}$ cfu/g in fresh matter) } \\
\hline Control & $3.99 \pm 0.05^{\mathrm{a}}$ & $7.02 \pm 0.10^{\mathrm{a}}$ & $6.94 \pm 0.16^{\mathrm{bc}}$ & $8.91 \pm 0.27$ & $8.30 \pm 0.10^{b}$ & $7.35 \pm 0.06$ \\
\hline Lactobacillus brevis (LS-55-2-2) & $3.87 \pm 0.09^{\mathrm{ab}}$ & $6.77 \pm 0.10^{\mathrm{ab}}$ & $7.43 \pm 0.09^{\mathrm{a}}$ & $9.14 \pm 0.17$ & $9.22 \pm 0.16^{\mathrm{ab}}$ & $7.30 \pm 0.23$ \\
\hline Lactobacillus citerum (LS-70-6-1) & $2.97 \pm 0.60^{\mathrm{abc}}$ & $6.32 \pm 0.05^{c}$ & $6.57 \pm 0.09^{\text {cd }}$ & $8.74 \pm 0.13$ & $10.79 \pm 0.87^{a}$ & $6.32 \pm 0.29$ \\
\hline Mean & 3.18 & 6.55 & 6.98 & 8.91 & 9.35 & 6.81 \\
\hline$p$-value & $* *$ & $* * *$ & $* * *$ & ns & * & ns \\
\hline
\end{tabular}

$T_{0}$, fresh plants before ensiling; $T_{6}$, six hours after ensiling; $T_{12}$, twelve hours after ensiling; $T_{24}$, twenty-four hours after ensiling; $T_{48,}$, forty-eight hours after ensiling; $T_{75} d$, seventy-five days after ensiling; ns, non-significant.

a-d Mean values with diffent superscripts have significant difference. ${ }^{*} p<0.05 ;{ }^{* *} p<0.01 ;{ }^{* *} p<0.001$. 
Table 4. Effects of different bacterial inoculants on numbers of yeasts and molds of ensiled silages at different silage opening times

\begin{tabular}{|c|c|c|c|c|c|c|}
\hline Inoculants & $\mathrm{T}_{0}$ & $T_{6}$ & $\mathrm{~T}_{12}$ & $\mathrm{~T}_{24}$ & $\mathrm{~T}_{48}$ & $T_{75} d$ \\
\hline \multicolumn{7}{|l|}{ Yeasts ( $\log _{10}$ cfu/g in fresh matter) } \\
\hline Control & $4.36 \pm 0.18$ & $4.73 \pm 0.13^{b}$ & $4.46 \pm 0.33^{b c}$ & $4.06 \pm 0.15^{\mathrm{a}}$ & $3.25 \pm 0.48^{\mathrm{a}}$ & nd \\
\hline Lactobacillus brevis (LS-55-2-2) & $4.66 \pm 0.18$ & $5.14 \pm 0.05^{b}$ & $5.08 \pm 0.18^{b c}$ & $2.59 \pm 0.06^{b}$ & $3.21 \pm 0.22^{\mathrm{a}}$ & nd \\
\hline Lactobacillus citerum (LS-70-6-1) & $3.92 \pm 0.24$ & $6.15 \pm 0.10^{a}$ & $4.64 \pm 0.07^{b c}$ & $4.35 \pm 0.56^{a}$ & $3.37 \pm 0.25^{\mathrm{a}}$ & nd \\
\hline Lactobacillus bifermentans (LS-65-2-1) & $4.00 \pm 0.00$ & $6.17 \pm 0.15^{\mathrm{a}}$ & $5.18 \pm 0.53^{\mathrm{abc}}$ & $2.26 \pm 0.14^{b}$ & $2.82 \pm 0.02^{\mathrm{a}}$ & nd \\
\hline Lactobacillus plantarum (LS-3-3) & $4.00 \pm 0.00$ & $5.73 \pm 0.08^{a}$ & $6.41 \pm 0.01^{\mathrm{a}}$ & $2.30 \pm 0.17^{b}$ & $1.26 \pm 0.14^{b}$ & nd \\
\hline Lactobacillus plantarum (LS-72-2) & $4.01 \pm 0.23$ & $5.04 \pm 0.17^{b}$ & $5.96 \pm 0.21^{\mathrm{ab}}$ & $2.26 \pm 0.14^{b}$ & $2.42 \pm 0.25^{\mathrm{ab}}$ & nd \\
\hline Mean & 4.16 & 5.49 & 5.29 & 2.97 & 2.72 & - \\
\hline p-value & ns & $* * *$ & $* *$ & $* * *$ & $* *$ & - \\
\hline \multicolumn{7}{|l|}{ Molds ( $\log _{10}$ cfu/g in fresh matter) } \\
\hline Control & $4.88 \pm 0.10^{\mathrm{a}}$ & $4.26 \pm 0.22^{\mathrm{a}}$ & $3.84 \pm 0.23^{\mathrm{a}}$ & $3.79 \pm 0.04^{\mathrm{a}}$ & $3.13 \pm 0.13^{\mathrm{ab}}$ & $1.30 \pm 0.00^{c}$ \\
\hline Lactobacillus brevis (LS-55-2-2) & $4.93 \pm 0.24^{\mathrm{a}}$ & $3.77 \pm 0.09^{\mathrm{ab}}$ & $3.67 \pm 0.09^{a b}$ & $2.79 \pm 0.10^{b c}$ & $3.49 \pm 0.17^{\mathrm{a}}$ & $1.69 \pm 0.20^{b c}$ \\
\hline Lactobacillus citerum (LS-70-6-1) & $4.41 \pm 0.29^{\mathrm{ab}}$ & $3.45 \pm 0.31^{b}$ & $2.59 \pm 0.06^{c}$ & $3.44 \pm 0.18^{\mathrm{ab}}$ & $2.71 \pm 0.11^{\mathrm{ab}}$ & $1.71 \pm 0.21^{\mathrm{abc}}$ \\
\hline Lactobacillus bifermentans (LS-65-2-1) & $3.95 \pm 0.05^{b}$ & $3.10 \pm 0.10^{b}$ & $2.59 \pm 0.15^{c}$ & $2.59 \pm 0.17^{c}$ & $2.58 \pm 0.18^{b c}$ & $2.38 \pm 0.19^{a}$ \\
\hline Lactobacillus plantarum (LS-3-3) & $3.93 \pm 0.19^{b}$ & $3.00 \pm 0.00^{b}$ & $3.25 \pm 0.15^{\mathrm{ab}}$ & $2.26 \pm 0.14^{c}$ & $1.65 \pm 0.35^{c}$ & $2.06 \pm 0.03^{\mathrm{ab}}$ \\
\hline Lactobacillus plantarum (LS-72-2) & $4.54 \pm 0.14^{b}$ & $3.70 \pm 0.10^{b c}$ & $3.05 \pm 0.03^{b c}$ & $2.70 \pm 0.20^{c}$ & $2.26 \pm 0.07^{b c}$ & $1.69 \pm 0.05^{b c}$ \\
\hline Mean & 4.44 & 3.55 & 3.17 & 2.93 & 2.64 & 1.81 \\
\hline p-value & ** & ** & $* * *$ & $* * *$ & $* * *$ & ** \\
\hline
\end{tabular}

$T_{0}$, fresh plants before ensiling; $T_{6}$, six hours after ensiling; $T_{12}$, twelve hours after ensiling; $T_{24}$, twenty-four hours after ensiling; $T_{48}$, forty-eight hours after ensiling; $T_{75} d$, seventy-five days after ensiling; nd, not detected; ns, non-significant.

a-c Mean values with diffent superscripts have significant difference. ${ }^{* *} p<0.01 ;{ }^{* *} p<0.001$.

duced less LA compared to control. L. citerum (LS-70-6-1) and L. plantarum (LS-3-3) produced the lowest PA and BA, respectively, which are unwanted fermentation products for silages. No ETOH content in any silage could be detected.

\section{Chemical composition and feed quality values of $T_{75} d$ silages}

Chemical composition and feed quality values of $\mathrm{T}_{75} \mathrm{~d}$ alfalfa silages inoculated with different bacterial isolates are shown in Tables 6, 7.

In terms of CP, $L$. plantarum (LS-72-2) treatment gave the highest values with $205.07 \mathrm{~g} / \mathrm{kg}$ DM while the lowest CP value was obtained from L. plantarum (LS-3-3) treatment with $166.19 \mathrm{~g} / \mathrm{kg}$ DM. NDF, ADF, DMI, and RFV were not affected significantly by the treatments. The highest ME and OMD were obtained from L. citerum (LS-70-6-1) with $9.55 \mathrm{MJ} / \mathrm{kg}$ DM and $57.33 \%$, respectively, while the lowest values were 8.76 MJ/kg DM from L. plantarum (LS-3-3), $4.39 \mathrm{MJ} / \mathrm{kg}$ DM and 52.25\% from L. plantarum (LS-72-2), respectively. Although the differences among treatments in terms of RFV, the highest value was 118.18 from L. bifermentans (LS-65-21) treatment and the lowest was 104.96 from L. brevis (LS55-2-2) treatment.

\section{DISCUSSION}

Some cell wall components such as NDF and ADF contents of alfalfa forage just before ensiling were similar to previously reported figures [22-25] meaning that they were within normal range. The $\mathrm{pH}$ value which is considered as a very

Table 5. Effects of different bacterial inoculants on volatile fatty acid contents of $T_{75} \mathrm{~d}$ silages

\begin{tabular}{|c|c|c|c|c|c|}
\hline \multirow{2}{*}{ Inoculants } & LA & AA & BA & PA & ETOH \\
\hline & \multicolumn{5}{|c|}{ 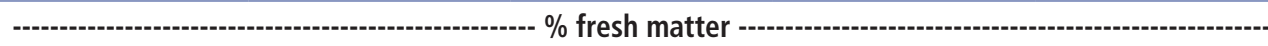 } \\
\hline Control & $1.048 \pm 0.27$ & $0.816 \pm 0.26$ & $1.509 \pm 0.46$ & $0.707 \pm 0.22$ & nd \\
\hline Lactobacillus brevis (LS-55-2-2) & $0.933 \pm 0.39$ & $0.604 \pm 0.09$ & $1.283 \pm 0.25$ & $0.543 \pm 0.08$ & nd \\
\hline Lactobacillus citerum (LS-70-6-1) & $1.369 \pm 0.14$ & $0.826 \pm 0.09$ & $1.142 \pm 0.09$ & $0.691 \pm 0.06$ & nd \\
\hline Lactobacillus bifermentans (LS-65-2-1) & $1.484 \pm 0.06$ & $0.900 \pm 0.11$ & $0.844 \pm 0.08$ & $0.561 \pm 0.05$ & nd \\
\hline Lactobacillus plantarum (LS-3-3) & $0.659 \pm 0.25$ & $1.250 \pm 0.30$ & $1.171 \pm 0.13$ & $0.754 \pm 0.13$ & nd \\
\hline Lactobacillus plantarum (LS-72-2) & $0.955 \pm 0.12$ & $1.454 \pm 0.12$ & $1.563 \pm 0.29$ & $0.868 \pm 0.04$ & nd \\
\hline Mean & 1.075 & 0.975 & 1.252 & 0.687 & - \\
\hline$p$-value & ns & ns & ns & ns & - \\
\hline
\end{tabular}

$L A$, lactic acid; $A A$, acetic acid; $B A$, butyric acid; $P A$, propionic acid; $E T O H$, ethanol; nd, not detected; ns, non-significant. 
Table 6. Effects of different bacterial inoculants on means of chemical compositions and gas production of ensiled silages opened at time $T_{75} d$

\begin{tabular}{lcccc}
\hline Inoculants & CP $(\mathbf{g} / \mathbf{k g}$ DM) & NG (mL/g) & NDF (g/kg DM) & ADF (g/kg DM) \\
\hline Control & $171.54 \pm 2.09^{\mathrm{bc}}$ & $214.33 \pm 2.70^{\mathrm{ab}}$ & $503.83 \pm 9.72$ & $396.73 \pm 14.51$ \\
Lactobacillus brevis (LS-55-2-2) & $173.48 \pm 0.31^{\mathrm{bc}}$ & $216.60 \pm 10.35^{\mathrm{ab}}$ & $527.62 \pm 40.22$ & $390.01 \pm 31.31$ \\
Lactobacillus citerum (LS-70-6-1) & $187.56 \pm 3.70^{\mathrm{abc}}$ & $230.96 \pm 1.02 \mathrm{a}$ & $523.90 \pm 18.59$ & $347.06 \pm 10.98$ \\
Lactobacillus bifermentans (LS-65-2-1) & $194.74 \pm 3.98^{\mathrm{ab}}$ & $223.27 \pm 1.24^{\mathrm{ab}}$ & $493.09 \pm 14.52$ & $338.80 \pm 4.88$ \\
Lactobacillus plantarum (LS-3-3) & $166.19 \pm 12.30^{\mathrm{c}}$ & $206.26 \pm 5.36^{\mathrm{b}}$ & $505.90 \pm 18.28$ & $381.64 \pm 11.83$ \\
Lactobacillus plantarum (LS-72-2) & $205.07 \pm 1.06^{\mathrm{a}}$ & $201.76 \pm 2.34^{\mathrm{b}}$ & $501.89 \pm 14.85$ & $333.85 \pm 3.47$ \\
Mean & 183.10 & 215.53 & 509.37 & 364.68 \\
p-value & $* *$ & $*$ & $n$ & $\mathrm{~ns}$ \\
\hline
\end{tabular}

CP, crude protein; DM, dry matter; NG, net gas; NDF, neutral detergent fiber; $A D F$, acid detergent fiber; ns, non-significant.

${ }^{a-c}$ Mean values with diffent superscripts have significant difference. ${ }^{*} p<0.05 ;{ }^{* *} p<0.01$.

important indicator for estimating fermentation profile and extent of fermentation quality of ensiled materials [26] were constant for all treatment at $\mathrm{T} 0$ as expected (Table 1). The $\mathrm{pH}$ values of control silages were generally higher than that of inoculated silages, indicating that inoculating in pre-harvesting period can induce a better fermentation compared to uninoculated silages. It is generally desired that the $\mathrm{pH}$ value be around 3.8 to 4.2 for any quality silage but this is usually not possible for silages from legumes. It is difficult to bring the $\mathrm{pH}$ below 5 for legume silages, especially with a relatively low DM content. However, in this study, measured $\mathrm{pH}$ values ranged between 4.70 and 5.52 for L. bifermentans (LS-65-2-1) and control silage, respectively, at the opening time $\mathrm{T}_{75} \mathrm{~d}$. Some researchers found that inoculated alfalfa, corn or sorghum silages had lower $\mathrm{pH}$ values than the control groups in their studies [27-29]. It can be speculated that a low $\mathrm{pH}$ value of inoculated alfalfa silage may be a result the efficiency of the strain of LAB nused in the experiment. $L$. bifermentans (LS-65-2-1) was the most effective strain in dropping $\mathrm{pH}$ at $\mathrm{T}_{75} \mathrm{~d}$ (Table 2).

The microbiological flora structure of alfalfa forage started to change as early as the first six hours of ensiling and it was widely altered even in the first 48 hours of ensiling except for enterobacteria. The yeasts numbers increased at $\mathrm{T}_{0}$ opening, then started to decrease till $\mathrm{T}_{48}$ opening time and they were undetectable in the $\mathrm{T}_{75} \mathrm{~d}$ silages. The number of molds started to decrease as soon as the forage was ensiled and continued to decrease as the ensiling duration was prolonged. The LAB content of silages generally increased, from $\mathrm{T}_{0}$ to $\mathrm{T}_{48}$. After $\mathrm{T}_{12}$, number of LAB in the silo passed the number of enterobacteria, yeast and mold and started to dominate fermentation in the silo. For a good quality silage fermentation, numerically higher LAB, the most significant species during ensiling [14], while lower counts of enterobacteria, yeast and mold are expected. The LAB numbers ranged from 6.11 to 7.35 $\log _{10} \mathrm{cfu} / \mathrm{g}$ fresh silage at $\mathrm{T}_{75} \mathrm{~d}$ in accordance with Pitt and Leibensperger [30] and Rooke [31].

The LA production in quantity and LA rate in total acid produced in silo are important parameters for evaluating feed value of silage. The LA production by a given LAB strain depends on many factors such as their number in microbiological flora [32], their proliferation rate, temperature of environment and strain's capacity to produce LA. In addition, low LA can cause proliferation of detrimental microorganisms, which are damaging to silage quality $[33,34]$. Among the selected strains according to their LA production potential, $L$. citerum (LS-70-6-1) and L. bifermentans (LS-65-2-1) came to forefront when considered for their LA production quantity in silo and LA rate in total fermentation products. Especially L. bifermentans (LS-65-2-1) strain produced $41.6 \%$ more LA than control silage and $125.2 \%$ more than L. plantarum (LS3-3) strain, which produced the lowest quantity of LA. Similarly,

Table 7. Effects of different bacterial inoculants on means of nutritive values of ensiled silages opened at the time $T_{75} d$

\begin{tabular}{lcccc}
\hline Inoculants & ME (MJ/kg DM) & OMD (\%) & DMI (\%) & RFV \\
\hline Control & $9.01 \pm 0.08^{\mathrm{ab}}$ & $54.26 \pm 0.46^{\mathrm{ab}}$ & $2.38 \pm 0.05$ & $107.09 \pm 2.21$ \\
Lactobacillus brevis (LS-55-2-2) & $9.08 \pm 0.28^{\mathrm{ab}}$ & $54.66 \pm 1.85^{\mathrm{ab}}$ & $2.30 \pm 0.18$ & $104.96 \pm 12.33$ \\
Lactobacillus citerum (LS-70-6-1) & $9.55 \pm 0.01^{\mathrm{a}}$ & $57.33 \pm 0.17^{\mathrm{a}}$ & $2.30 \pm 0.08$ & $110.18 \pm 5.14$ \\
Lactobacillus bifermentans (LS-65-2-1) & $9.38 \pm 0.06^{\mathrm{ab}}$ & $55.99 \pm 0.25^{\mathrm{ab}}$ & $2.44 \pm 0.07$ & $118.12 \pm 3.80$ \\
Lactobacillus plantarum (LS-3-3) & $8.76 \pm 0.21^{\mathrm{b}}$ & $52.85 \pm 0.98^{\mathrm{b}}$ & $2.38 \pm 0.09$ & $109.04 \pm 4.04$ \\
Lactobacillus plantarum (LS-72-2) & $8.86 \pm 0.08^{\mathrm{ab}}$ & $52.25 \pm 0.51^{\mathrm{b}}$ & $2.44 \pm 0.07$ & $116.77 \pm 3.70$ \\
Mean & 9.11 & 54.56 & 2.37 & 111.03 \\
p-value & $*$ & $*$ & $\mathrm{~ns}$ & $\mathrm{~ns}$ \\
\hline
\end{tabular}

$\mathrm{ME}$, metabolizable energy; OMD, organic matter digestibility; DMI, dry matter intake; RFV, relative feed value; ns, non-significant.

$a, b$ Mean values with diffent superscripts have significant difference. ${ }^{*} p<0.05$. 
LA rate in total fermentation products of $L$. bifermentans (LS65-2-1) strain was $39.1 \%$ while that of control silage was $25.7 \%$, showing that L. bifermentans (LS-65-2-1) strain dominated fermentation in silo during ensiling. The L. bifermentans (LS65-2-1) inoculation decreased BA and PA content of silage compared to control silage at $44.1 \%$ and $20.7 \%$, respectively. Many researchers reported that the bacterial treatments increased LA and reduced AA for inoculated silages compared to uninoculated ones $[27,28,35]$.

The CP is the critical factor affecting the quality of commercial feeds and roughage for ruminants [34]. The CP content of alfalfa silages changed between 166.19 and $205.07 \mathrm{~g} / \mathrm{kg}$ $\mathrm{DM}$ for $\mathrm{T}_{75} \mathrm{~d}$ opening time. Except for L. plantarum (LS-33) treatment, higher CP content was achieved from all of the bacterial inoculation. Especially L. plantarum (LS-722-2) and L. bifermentans (LS-65-2-1) inoculations which produced $13.5 \%$ and $19.6 \%$ higher protein content, respectively, of $\mathrm{T}_{75} \mathrm{~d}$ silages compared to control. This may mean that protein degradation (proteolysis), which is influenced by several factors such as $\mathrm{pH}$ level, buffering capacity of raw material and VFA contents of silages, was less in these treatments than control silages. Gas production, which is basically the result of fermentation of carbohydrates to acetate, propionate and butyrate, while the contribution to gas production from protein fermentation is relatively small [36,37]. Since the cellulose and hemicellulose are digested to a certain extent by ruminant animals, NDF and ADF content of feeds are very important parameters affecting digestibility and feed intake by ruminants [36,37]. The NDF values obtained from this study, a mean of $50.94 \%$, was higher than the desired rate that is around $25 \%$ to $32 \%$ reported by Tekce and Gul [38]. The lowest NDF and ADF from this study were obtained from L. bifermentans (LS-65-2-1) and L. plantarum (LS-72-2) with $493.09 \mathrm{~g} / \mathrm{kg} \mathrm{DM}$ and $333.85 \mathrm{~g} / \mathrm{kg} \mathrm{DM}$, respectively. Inoculated silages with LAB strains didn't affect the NDF and ADF contents statistically as reported by Przemysław et al [39], Đorđević et al [40], and Ce et al [41].

Higher intake and improved animal performance are associated with well fermented, highly digestible silages containing high concentrations of lactic acid, and low AA and lignocellulosic structure [42]. Gonzalez et al [43] reported that fermentation of soluble carbohydrates and protein in the silo might cause a lower content of digestible organic matter compared to the control. In the present study, LAB inoculants positively affected ME, OMD, DMI, and RFV parameters. When overall parameters are taken into consideration, L. bifermentans (LS-65-2-1) was generally the outstanding strain compared to the others.

\section{IMPLICATIONS}

The LAB strains used in this study positively affected fermen- tation properties and feed quality parameters of treatments compared to control. It can be speculated that L. bifermentans (LS-65-2-1) strain was superior in terms of many parameters evaluated in the present study. The strain was isolated from the natural areas of Turkey and selected as a high LA producer strain. This strain can be registered based upon positive results obtained from current research and after the studies comparing it with commercial ones.

\section{CONFLICT OF INTEREST}

We certify that there is no conflict of interest with any financial organization regarding the material discussed in the manuscript.

\section{ACKNOWLEDGMENTS}

The microbial materials used in this study were isolated within the scope of project supported by TUBITAK (Scientific and Technological Research Council of Turkey) with an ID No: 1100694.

This study was conducted as MSc thesis.

\section{REFERENCES}

1. Tao L, Zhou H, Zhang N, et al. Effects of different source additives and wilt conditions on the $\mathrm{pH}$ value, aerobic stability, and carbohydrate and protein fractions of alfalfa silage. Anim Sci J 2017;88:99-106. https://doi.org/10.1111/asj.12599

2. McDonald P, Henderson AR, Heron SJE. The biochemistry of silage. Abersyth, UK: Chalcombe Publication; 1991.

3. Phelan P, Moloney AP, McGeough EJ, et al. Forage legumes for grazing and conserving in ruminant production systems. CRC Crit Rev Plant Sci 2014;34:281-326. https://doi.org/10. 1080/07352689.2014.898455

4. Wen A, Yuan X, Wang J, Desta ST, Shao T. Effects of four shortchain fatty acids or salts on dynamics of fermentation and microbial characteristics of alfalfa silage. Anim Feed Sci Technol 2017;223:141-8. https://doi.org/10.1016/j.anifeedsci.2016. 11.017

5. Repetto JL, Echarri V, Aguerre M, Cajarville J. Use of fresh cheese whey as an additive for lucerne silages: effects on chemical composition, conservation quality and ruminal degradation of cell walls. Anim Feed Sci Technol 2011;170:160-4. https:// doi.org/10.1016/j.anifeedsci.2011.09.004

6. McDonald P, Henderson AR, Heron SJE. The biochemistry of silage, 2nd ed. Marlow, UK: Chalcombe Publications; 1981.

7. Singh K, Honig H, Wermke M, Zimmer E. Fermentation pattern and changes in cell wall constituents of straw-forage silages, straws and partners during storage. Anim Feed Sci Technol 1996;61:137-53. https://doi.org/10.1016/0377-8401 (96)00953-4 
8. Davies DR, Merry RJ, Williams AP, Bakewell EL, Leemans DK, Tweed JKS. Proteolysis during ensilage of forages varying in soluble sugar content. J Dairy Sci 1998;81:444-53. https:// doi.org/10.3168/jds.S0022-0302(98)75596-1

9. McAllister TA, Feniuk R, Mir Z, Mir P, Selinger LB, Cheng $\mathrm{K}-\mathrm{J}$. Inoculants for alfalfa silage: Effects on aerobic stability, digestibility and the growth performance of feedlot steers. Livest Prod Sci 1998;53:171-81. https://doi.org/10.1016/ S0301-6226(97)00150-4

10. Kızılşimşek M, Erol A, Ertekin İ, Dönmez R, Katrancı B. Relationship among silage micro flora and their effects on silage fermentation and quality. KSU J Agric Nat Sci 2016;19:13640. https://dx.doi.org/10.18016/ksujns.35488

11. Weinberg ZG, Muck RE. New trends and opportunities in the development and use of inoculants for silage. FEMS Microbiol Rev 1996;19:53-68. https://doi.org/10.1016/0168-6445(96) 00025-3

12. Zielińska K, Fabiszewska A, Stefańska I. Different aspects of Lactobacillus inoculants on the improvement of quality and safety on alfalfa silage. Chilean J Agric Res 2015;75:298-306. http://dx.doi.org/10.4067/S0718-58392015000400005

13. Muck RE. Recent advances in silage microbiology. Agric Food Sci 2013;22:3-15. https://doi.org/10.23986/afsci.6718

14. Yitbarek MB, Tamir B. Silage additives: review. Open J Appl Sci 2014;4:258-74. http://dx.doi.org/10.4236/ojapps.2014. 45026

15. AOAC, Association of Official Analytical Chemists. Official method of analysis. 15th ed., Washington, USA: AOAC International; 1990. pp. 66-88.

16. Van Soest PJ, Robertson JB, Lewis BA. Methods for dietary fiber, neutral detergent fiber and nonstarch polysaccharides in relation to animal nutrition. J Dairy Sci 1991;74:3583-97. https://doi.org/10.3168/jds.S0022-0302(91)78551-2

17. Menke KH, Steingass H. Estimation of the energetic feed value obtained from chemical analysis and in vitro gas production using rumen fluid. Anim Res Dev1988;28:7-55.

18. Blümmel M, Orskov ER. Comparison of in vitro gas production and nylon bag degradability of roughages in predicting feed intake in cattle. Anim Feed Sci Technol 1993;40:109-19. https://doi.org/10.1016/0377-8401(93)90150-I

19. Menke KH, Raab L, Salewski A, Steingass H, Fritz D, Schneider W. The estimation of the digestibility and metabolizable energy content of ruminant feedingstuffs from the gas production when they are incubated with rumen liquor in vitro. J Agric Sci 1979;93:217-22. https://doi.org/10.1017/S0021859600 086305

20. Van Dyke NJ, Anderson PM. Interpreting a forage analysis. Alabama cooperative extension system; 1998. Report No.: ANR-890.

21. Quiros ARB, Yusty MAL, Hernandez JL. HPLC analysis of organic acids using a novel stationary phase. Talanta 2009;78: 643-6. https://doi.org/10.1016/j.talanta.2008.11.013
22. Holden LA. Comparison of methods of in vitro dry matter digestibility for ten feeds. J Dairy Sci 1999;82:1791-4.

23. Sturgeon LS, Baker LA, Pipkin JL, Haliburton JC, Chisare NK. The digestibility and mineral availability of mutual, bermuda grass and alfalfa hay in mature horses. J Equine Vet Sci 2000; 20:45-8. https://doi.org/10.1016/S0737-0806(00)80320-2

24. Jeranyama $P$, Garcia $A D$. Understanding relative feed value (RFV) and relative forage quality. South Dakota State University: Cooperative Extension Service: Extension Extra; 2004. p. 352-4.

25. Palmquist DL. Influence of source and amount of dietary fat on digestibility in lactating cows. J Dairy Sci 1991;74:135460. https://doi.org/10.3168/jds.S0022-0302(91)78290-8

26. Denek N, Can A, Avci M, Aksu T, Durmaz H. The effect of molasses-based pre-fermented juice on the fermentation quality of first-cut lucerne silage. Grass Forage Sci 2011;66:243-50. https://doi.org/10.1111/j.1365-2494.2011.00783.x

27. Filya I. The effect of Lactobacillus buchneri and Lactobacillus plantarum on the fermentation, aerobic stability, and ruminal degradability of low dry matter corn and sorghum silages. J Dairy Sci 2003;86:3575-81. https://doi.org/10.3168/jds.S00220302(03)73963-0

28. Kizilsimsek M, Schmidt RJ, Kung L Jr. Effects of a mixture of lactic acid bacteria applied as a freeze-dried or fresh culture on the fermentation of alfalfa silage. J Dairy Sci 2007;90:5698705. https://doi.org/10.3168/jds.2007-0448

29. Filya I, Muck RE, Contreas-govea FE. Inoculant effects on alfalfa silage: Fermentation products and nutritive value. J Dairy Sci 2007;90:5108-14. https://doi.org/10.3168/jds.2006877

30. Pitt RE, Leibensperger RY. The effectiveness of silage inoculants: a systems approach. Agric Syst 1987;25:27-49. https:// doi.org/10.1016/0308-521X(87)90097-7

31. Rooke JA. The numbers of epiphytic bacteria on grass at ensilage on commercial farms. J Sci Food Agric 1990;51:525-33. https://doi.org/10.1002/jsfa.2740510409

32. Muck RE. Silage microbiology and its control through additives. R Bras Zootec 2010;39:183-91. http://dx.doi.org/10.1590/ S1516-35982010001300021

33. Kızılşimşek M, Küsek M, Gezginç Y, Erol A. Isolation and identification of high lactic acid producer bacteria from forage and their silages grown in different ecologies. Kafkas Vet Fak Derg 2016;22:291-6. https://doi.org/10.9775/kvfd.2015.14291

34. Silva VP, Pereira OG, Leandro ES, et al. Effects of lactic acid bacteria with bacteriocinogenic potential on the fermentation profile and chemical composition of alfalfa silage in tropical conditions. J Dairy Sci 2016;99:1895-902. https://doi.org/10. 3168/jds.2015-9792

35. Schmidt RJ, Hu W, Mills JA, Kung Jr L. The development of lactic acid bacteria and Lactobacillus buchneri and their effects on the fermentation of alfalfa silage. J Dairy Sci 2009;92:500510. https://doi.org/10.3168/jds.2008-1701 
36. Yavuz M. Determination of some ruminant feeds' relative feed value and in vitro digestion values. Gaziosmanpaşa Üniv Zir Fak Derg 2005;22:97-101.

37. Canpolat Ö, Karaman Ş. Comparison of in vitro gas production, organic matter digestibility, relative feed value and metabolizable energy contents of some legume forages. Tar Bil Der 2009;15:188-95.

38. Tekce E, Gül M. the importance of NDF and ADF in ruminant nutrition. Atatürk Üniversitesi Vet Bil Derg 2014;9:63-73. https://doi.org/10.17094/avbd.34439

39. Przemysław S, Cezary P, Stanisław M, et al. The effect of nutritional and fermentational characteristics of grass and legume silages on feed intake, growth performance and blood indices of lambs. Small Rumin Res 2015;123:1-7. https://doi.org/10. 1016/j.smallrumres.2014.11.008

40. Đorđević S, Mandić V, Stanojević, D. The effect of bacterial inoculant on chemical composition and fermentation of alfalfa silage. Biotechnol Anim Husb 2016;32:413-23. https://doi. org/10.2298/BAH1604413D

41. Ce L, Yu-jiao L, Xiao-nan L, Ping-ting G, Hai-ling L. Effect of lactic acid bacteria inoculants on alfalfa (Medicago sativa L.) silage quality: assessment of degradation (in situ) and gas production (in vitro). J Integr Agr 2016;15:2834-41. https:// doi.org/10.1016/S2095-3119(16)61424-7

42. Buxton DR, Mertens DR. Quality-related characteristics of forages. In: Barnes RF, Miller DA, Nelson CJ, editors. The science of grassland agriculture. Ames, IA, USA: Iowa State University Press; 1995. pp. 83-96.

43. González J, Faría-Mármol J, Rodríguez CA, Martínez A. Effects of ensiling on ruminal degradability and intestinal digestibility of Italian rye-grass. Anim Feed Sci Technol 2007;136:38-50. https://doi.org/10.1016/j.anifeedsci.2006.08.022 